\title{
Phenology of Croton blachetianus Baill in a dry tropical forest associated with the dynamics of temporal variability of rainfall
}

\author{
Alberício Pereira de Andrade ${ }^{1,2}$, João Luciano de Andrade Melo Junior ${ }^{1,3 *}$, Riselane de Lucena Alcântara \\ Bruno $^{2}$, André Luiz Rodrigues Magalhães ${ }^{1}$, Luan Danilo Ferreira de Andrade Melo ${ }^{3}$, Divan Soares da Silva ${ }^{2}$, \\ Roberta de Lima Valença ${ }^{1}$
}

\author{
${ }^{1}$ Rural Federal University of Pernambuco, Garanhuns Academic Unit, Av. Bom Pastor, s/n - Boa Vista, \\ Garanhuns, PE, Brazil \\ ${ }^{2}$ Federal University of Paraíba, Center of Agricultural Sciences, 12 Highway, PB-079, Areia, PB, Brazil \\ ${ }^{3}$ Federal University of Alagoas, Center of Agricultural Sciences, BR-104, Rio Largo, AL, Brazil
}

\author{
*Corresponding author : luciiano.andrade@yahoo.com.br
}

\section{Abstract}

In the semi-arid environment, the synchronism and the magnitude of the precipitation pulses are indispensable for the ecological processes, mainly due to the availability of water in the soil for the plants and to the microbiological activity of the soil. The present study aimed to determine the vegetative and reproductive phenological behavior of Croton blachetianus Baill in areas of Caatinga. The hypothesis was that the occurrence of the phenophases is synchronized with the spatial and temporal distribution of the precipitation pulses, under semi-arid conditions. For the phenological study, 50 tree individuals were selected, marked and monitored weekly, recording the presence and absence of the phenophases of sprouting, appearance of flower buds, flowering (anthesis), fruiting and senescence, whose data were related to the water pulses and inter-pulses. The method proposed by Fournier was used to estimate the percentage of the intensity of the phenophases in each individual. The phenological data of intensity of each phenophase (sprouting, flower-bud, flowering, fruiting and senescence) were related to the distribution of rain pulses and through Spearman's correlation coefficient, using the number of individuals under each phenophase and the daily climate data. The vegetative and reproductive phenological behavior of $C$. blachetianus reflected the seasonal pattern of precipitation. The intensity and duration of the phenophases depended on the extent and frequency of the rain pulses during the rainy season. Total leaf senescence happened when the precipitation inter-pulses intensified as the dry season progressed, characterizing deciduousness.

Keywords: Phenophases; Pulses and inter-pulses of precipitation; Semi-arid.

Introduction

Phenology is the study of the occurrence of repetitive biological events and the causes of their occurrence in relation to the selective biotic and abiotic forces and their interrelationship between the phases characterized by these events, within the same or several species (Bassaco and Nogueira, 2019). In this way, phenology contributes to the understanding of plant regeneration and reproduction, temporal organization of resources within communities, plant-animal interactions and the evolution of the life history of animals that depend on plants for food, such as herbivores, pollinators and dispersers (Braga et al., 2019).

In the semi-arid regions while temperature, solar radiation and nutrient inputs in the ecosystem vary during the year, precipitation usually occurs in discontinuous events, in the form of pulses of relatively short duration. The synchronism and the magnitude of the precipitation pulses are indispensable for the ecological processes, mainly with respect to the availability of water in the soil for the plants and the microbiological activity of the soil. These rain pulses drive the processes at large scales, and consequently, their transformation into available water for the plants is more complex (Lima et al., 2018).

The Caatinga is a biome typically found in the Northeast of Brazil, which presents high vegetal and animal biodiversity, despite the water scarcity. The inhabitants of this environment have developed adaptations that allow their survival in the semi-arid climate (Ribeiro et al., 2018). The studies in these regions are important, especially to understand the dynamics of the dry forests, the seasonal droughts are more than those occurring in non-seasonal forests (Paz and Souza, 2018). By the general theory of coexistence, in the semi-arid environment, rainfall variability stimulates specific mechanisms that contribute to the maintenance of species diversity, such as those of the Caatinga.

Understanding how rain affects biodiversity, composition and dynamics of the species in the semi-arid environment, contributes to the definition of strategies for the exploitation of native plants with agricultural and forage potential, as well as to minimize the degradation of this 
ecosystem. It is also important to understand the specificities of the physiological and morphological characteristics of the different Caatinga species, since these are the ones that guarantee the survival and growth of the plants and ensure their biodiversity.

The genus Croton is considered the second largest genus of the family Euphorbiaceae with approximately 1,200 species distributed predominantly in the American continent. Brazil is considered one of the main centers of diversity of the group, with about 300 species. The species Croton blanchetianus Baill., popularly known as marmeleiro preto, being a shrub widespread in northeastern Brazil. This species presents rapid growth with ecological and timber production potentials. $C$. blanchetianus has a remarkable ability to adapt to global climate change and can be considered a model in studies that explore the relationships of water in woody plants. Consequently, this species may be important in future reforestation studies (Mendes et al., 2017). Leaves and peels are commonly used in folk medicine for the treatment of gastrointestinal disorders, rheumatism headache, and edema.

The present study aimed to determine the reproductive and vegetative phenological patterns of $C$. blanchetianus in areas of hyperoxerophilic Caatinga. Our working hypothesis is that, under semi-arid conditions, the occurrence of the phenophases is synchronized with the spatial and temporal distribution of the precipitation pulses.

\section{Results and discussion}

Fournier's percent index shows the peaks of intensity, indicating a given phenophase occurrence more intensively in the population. This emphasizes the estimated quantity of sprouting, senescence, flower buds, flowers and fruits produced and not only the number of individuals displaying a given phenophase. In this context, we can observe that the leaf sprouting phenophase is an event that takes place as soon as the precipitation pulses in the rainy season start (Figure 1).

In May 2008 (237 JD), sprouting was intense with a peak of $100 \%$ at 311 JD (August 2008) as soon as the rains began. Although the intensity of the sprouting peak in 2010 was similar to that of 2008, it varied when the event took place (417 JD - February) due to distribution of rains (Figure 1). C. blachetianus has a quick response of leaf emergence to the rain pulses, reaching its highest peak in few days. These pulses have some degree of regular distribution so that the plant does not undergo strong water shortages. Additionally, the duration of leaf sprouting is short and highly intense. Consequently, the crown of plant is immediately covered by leaves in very few days.

Previously focused approaches are based on the "reserve pulse" model, which describes a simple and direct relationship between rainfall events, which provoke a "pulse" and primary production. In turn, results in carbon and energy reserves that are accumulated in the seeds and in the assimilated production organs of the plant. These reserves are considered inactive until a pulse restarts. When rainfall is not considered to be important from a biological point of view, it triggers changes in physiological and morphological processes. These reserves slowly decrease over time (because of respiration, abscision, senescence, herbivory, among others). However, in rainy periods, the intervals between each event can stimulate the plant growth pulses, and consequently the recovery of these reserves.
The sprouting phenophase began to decrease with the beginning of the intercurrent rainy season up to 159 Julian days (December 2008). The two pulses of precipitation (179185 and 201-207 JD) were not sufficient to cause sprouting to start because these were discrete low-intensity rain events. However, when precipitation pulses predominate, the water available in the soil for the plants is reduced. Consequently, C. blachetianus starts its leaf senescence, which in 2008 occurred between 263 JD (June 2008) at 366 JD (beginning of January 2010). In 2010, this transition took place between July and August, corresponding to the 547625 JD interval (values accumulated since 2009) (Figure 1). The greatest leaf abscission was activity occurred with the beginning of the dry period, confirming the deciduous habit of the species, in which the highest peaks of leaf fall were recorded in mid-August (Figure 1). The complete loss of leaves during the driest period of the year may be related to the water deficit, causing the gas exchanges to decrease, including the exchange of water between the leaves and the environment. Leaf abscission represents a response to water stress. So, it is involved in the capacity to withstand water loss, which varies according to the tree species found in the Caatinga.

The semi-arid environments are characterized not only by the limited amount of water but also by the temporal and spatial variation of precipitation (local and regional). Typically, rainfall events cause concise pulses of soil water content from infiltration due to the small effective depth of most soils in the region. It should also be considered that precipitation events are never evenly spaced in time, and the probability of occurrence of these events increases during the rainy season. When the rains come together and evapotranspiration is lower, the possibility of reserving water in the soil for plants increases (Silva et al., 2017).

Logically, in the conditions of the northeastern Semi-arid, where the majority of the soils have little depth, the amplitude of variation of the availability of water between layers of the soil tends to diminish, due to its smaller capacity of storage of water that varies of temporal form and space. Thus, the plants have a shorter time of use of the soil water reserve in this ecosystem (Brand, 2017).

Flowering started after the opening of flower buds, appearing once every year. In 2008, the flowering peak (47\%) was occurred at $207 \mathrm{JD}$, as soon as there was a pulse of rain (Figure 2). These results confirm the dependency of C. blachetianus on the rain to flower, as occurs with sprouting (Figure 1). In 2010, the onset of flowering was at 417 JD (February 2010), with a duration of up to 547 JD (July), reaching its peak (45\%) at 469 JD (April 2010) (Figure 2). These data allow us to infer that the referred species has an annual reproductive pattern. The appearance of flowers in the transition from the dry season to the beginning of the rainy season in areas of the Caatinga has been attributed mostly to the decrease in water stress caused by the first rains after the dry period and to the temperature increase (Leal et al., 2018).

In 2008, response of $C$. blachetianus to the rain pulses was fruiting period from 207 to 311 JD, corresponding to the months of April to August, with a peak (53\%) at 237 JD (Figure 2). From this point on, there were no plants producing fruits, because they were in the process of physiological maturation and consequent natural dehiscence. That precipitation pulses are inducers of physiological activities in the vegetation of the Caatinga and 


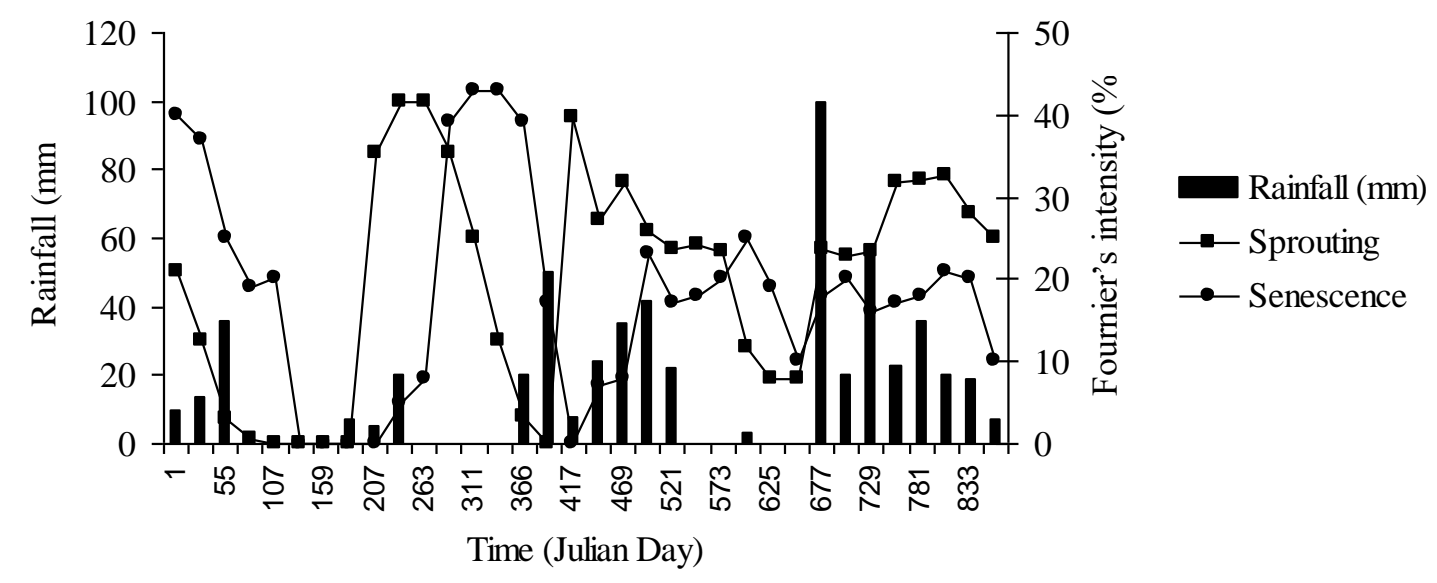

Fig 1. Fournier's percent index shown by C. blachetianus in the sprouting and senescence phenophases and daily rainfall (20072011).

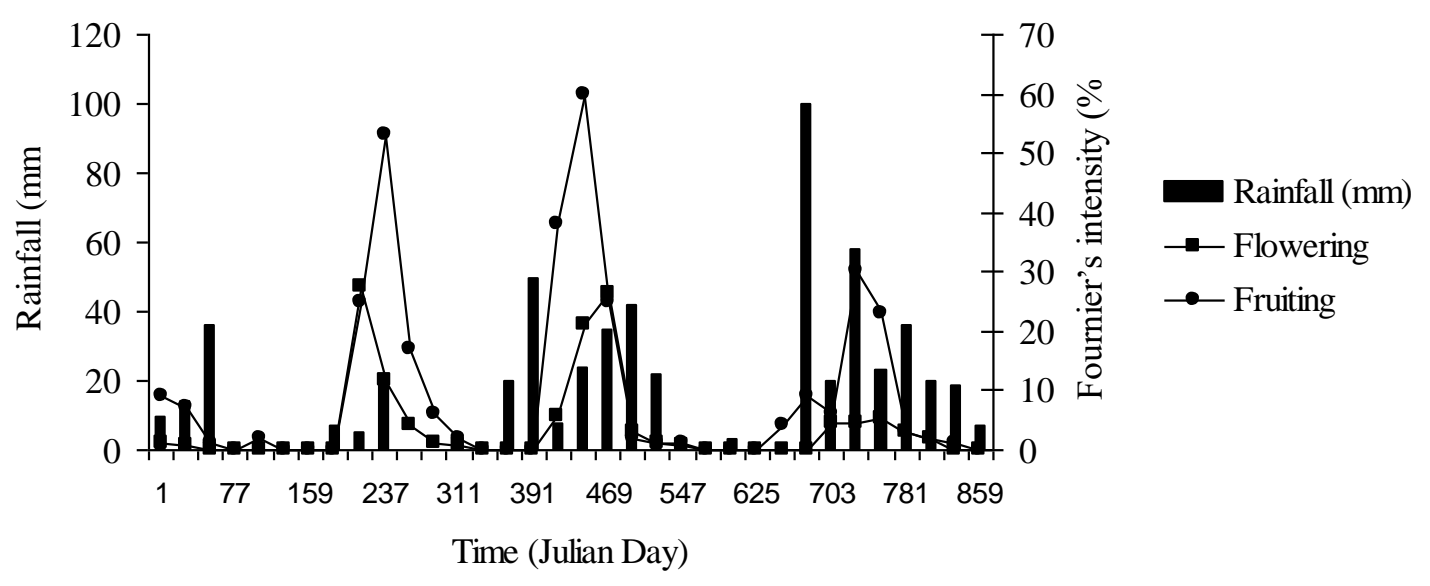

Fig. 2. Fournier's percent index shown by $C$. blachetianus in the flower-bud, flowering and fruiting phenophases during the experiment (2007-2011).

they are responsible for the onset of plant growth and development.

In 2010, fruiting started in February (417 JD) and lasted until July (547 JD), with a peak of 60\% in March (443 JD). In 2011, the formation of fruits began in January (651 JD), with peak of (30\%) at $729 \mathrm{JD}$ (Figure 2). Although the intensity of the fruiting peak in the three years of study was occurred in different periods, this phenophase also depends on the distribution of rains.

Phenological events of other Semi-arid species also showed an accentuated seasonality in relation to precipitation: Cnidoscolus quercifolius (Oliveira et al., 2019), Copernicia prunifera (Rocha et al., 2015), Dipteryx odorata, Cordia oncocalyx, Poincianella pyramidalis, Manihot pseudoglaziovii, Handroanthus heptaphyllus, Pseudobombax marginatum (Souza et al., 2014) and Dalbergia cearensis (Nogueira et al., 2013).

In the semi-arid region, seasonal fluctuations in temperature and day length are insignificant to the alternation of rainy and dry periods. Furthermore, variations in the intensity of solar radiation strongly influence the periodic phenomena that determine the vegetative and reproductive growth of perennial and annual plant species. The stimulus to flowering can be caused by the appearance of new leaves, although some species of the Semi-arid region present the phases of flowering and fruiting after the fall of their leaves (Parente et al., 2012).

Finally, it should be considered that in any system of exploitation of the Caatinga, it is important to understand that those who regulate the dynamics of the vegetation are the pulses of water reserve of the soil, which concomitantly are associated with the pulses and inter-pulses of the rains. The pulses of precipitation are like inductors ("triggers") that trigger the physiological activities, determining the growth and development of the vegetation of the Caatinga (Amorim et al., 2009).

It is also important to emphasize that rainfall variability does not reduce the importance of interactions between species in the structuring of the Caatinga plant communities, and that it is necessary to define lines of ecological differentiation among the species that help in their coexistence. These rain pulses still influence all trophic levels and the entire food chain. 
In addition, Caatinga soils are generally young and shallow, favoring surface runoff, and explains the fact that less phenological intensity occurs even with high rainfall. This corroborates the idea that the phenophases would be more related to the synchronous distribution of rainfall.

\section{Materials and methods}

The field study was conducted on Experimental Station of the Federal University of Paraíba, located in the municipality of São João do Cariri, Paraíba State (PB), Brazil, at coordinates -70 23' 30" latitude and -360 31' 59" longitude. The predominant relief in the area is mildly undulated with an altitude of approximately $458 \mathrm{~m}$ in relation to the sea level.

The region is characterized by having a hot and dry climate; according to the Köppen (1948) classification, it is a semiarid type, $\mathrm{BS}^{\prime} \mathrm{h}$ subtype, with an average annual precipitation of $400 \mathrm{~mm}$, maximum and minimum temperatures of 27 and 23.1 으, respectively, with small variations over the year, and relative air humidity around $70 \%$.

Over the course of the experiment, daily records of precipitation were collected at Experimental Station of the Federal University of Paraíba, in São João do Cariri/PB.

The soils of the study area are mostly shallow, relatively plain to mildly undulated. They are on a crystalline geological structure where the most present types are: Chromic vertic luvisol - tc (Noncalcic brown vertic), Chromic orthic vertisol - vc (Vertisol) and Lithic entisol - rl (Litholic soil). There is also, in small proportions, Eutric Cambisol - cx (Cambisol), Eutric Fluvisol - ru (Alluvial soil), Haplic planosol - sx (Planosol sco) and rocky outcrops with evidence of Lithic entisol (Chaves et al., 2002).

The vegetation of the region corresponds to the hyperxerophilic Caatinga, and is in an accelerated process of degradation, due to the indiscriminate use of the areas, firstly for cotton cultivation, then for the extraction of wood and concomitantly by the extensive cattle ranching.

To select individuals, the sampling method was the quadrat method (an adaptation of the 'plots' method): ten quadrants (approximately $10 \times 10 \mathrm{~m}$ ) within the experimental area were selected so as to represent the entire Caatinga area of the Experimental Station of the Federal University of Paraíba. The criterion for inclusion of individuals was marking a reference spot in every quadrant and selecting the five closest individuals in the north, south, east and west directions. Fifty trees with similar size, having a trunk with minimum diameter at breast height greater than or equal to $20 \mathrm{~cm}$ were selected. Plants were identified with aluminum plates and non-wovenfabric (TNT) ribbons to be better visualized.

The observations were performed in weekly intervals, recording the presence and absence of the sprouting, flower-bud, full flowering, fruiting and leaf senescence phenophases. These phases were defined as follows: sprouting (emergence of leaves) - initially characterized by the presence of leaf primordia, usually of light-green or reddish color, ending when leaves acquired a dark green color; buds - period that starts when reproductive buds appear at the apical region of the branches and ends when flowers start opening (anthesis); flowering - period when the tree is at full bloom; fruiting - starts from the moment it is possible to visualize the small fruits after the flowers are fertilized and ends with dispersion of the seeds; senescence - period when the leaves change their color from dark green to brown and the spontaneous leaf abscission starts, forming empty spaces (flaws) at the crown or branches (Leal et al., 2007).

\section{Evaluation methods}

\section{Fournier's intensity percentage}

In this method, proposed by Fournier (1974), the values obtained in the field with a five-category (0 to 4$)$, semiquantitative interval scale with an interval of $25 \%$ between each category allowed us to estimate the percentage of the phenophase intensity in each individual. Every week, the intensity values obtained for all individuals of the species were summed and divided by the highest maximum possible value (number of individuals multiplied by five). The result, corresponding to a ratio, was then multiplied by 100 , to be converted into percentage terms.

\section{Statistical analysis}

The phenological data of intensity of each phenophase (sprouting, flower-bud, flowering, fruiting and senescence) were related to the distribution of rain pulses and through Spearman's correlation coefficient (Zar, 1996), using the number of individuals under each phenophase and the daily climate data, with the help of the SAS 9.2 software (SAS, 2008).

\section{Conclusions}

The vegetative and reproductive phenological patterns of $C$. blachetianus reflect the seasonal pattern of rainfall. The intensity and duration of the phenophases depends on the extent and frequency of the rain pulses during the rainy season. Total leaf senescence happens when the precipitation inter-pulses intensify as the dry season progresses, characterizing deciduousness.

\section{References}

Amorim IL, Sampaio EVSB, Araújo EL (2009) Fenologia de espécies lenhosas da Caatinga do Seridó, RN. Rev Árvore. 33(3): 491-499.

Bassaco MVM, Nogueira AC (2019) Comportamento fenológico de Sebastiania brasiliensis em Floresta Ombrófila Mista Aluvial. Biotemas. 32(2): 45-53.

Braga AMS, Lima GA, Teodoro MS, Lemos JR (2019) Fenologia de três espécies arbóreas em um trecho de vegetação subcaducifólia no norte do Piauí, Brasil. Biotemas. 32(2): 3344.

Chaves LHG, Chaves IB, Vasconcelos ACF, Silva APP (2002) Salinidade das águas superficiais e suas relações com a natureza dos solos na Bacia Escola do Açude Namorado e diagnóstico do uso e degradação das terras. Universidade Federal da Paraíba, Campina Grande, Brasil. 114 p.

Fournier LA (1974) Un método cuantitativo para la medición de características fenológicas en árboles. Turrialba. 24: 422423.

Köppen W (1948) Climatologia; com un estudio de los climas de la tierra. Fondo de Cultura Economica, México. $478 \mathrm{p}$.

Leal IR, Lopes AV, Machado IC, Tabarelli M (2018) Interações planta-animal na Caatinga: visão geral e perspectivas futuras. Cien Cult. 70(4): 35-40. 
Leal IR, Perini MA, Castro CC (2007) Estudo fenológico de espécies de Euphorbiaceae em uma área de Caatinga. p. 1-2. In Anais do VIII Congresso de Ecologia do Brasil, Caxambu. 23-28 September. Caxambu, Minas Gerais, Brasil.

Lima CR, Bruno RLA, Andrade AP, Pacheco MV, Quirino ZGM, Silva KRG, Belarmino KS (2018) Fenologia de Poincianella pyramidalis (Tul.) L. P. Queiroz e sua relação com a distribuição temporal da precipitação pluvial no Semiárido brasileiro. Ci Fl. 28(3): 1035-1048.

Mendes KR, Granja JAA, Ometto JP, Antonino ACD, Menezes RSC, Pereira EC, Pompelli MF (2017) Croton blanchetianus modulates its morphophysiological responses to tolerate drought in a tropical dry forest. Functional Plant Biol. 44(10): 1039-1051.

Nogueira FCB, Pacheco Filho AJS, Gallão MI, Bezerra AME, Medeiros Filho S (2013) Fenologia de Dalbergia cearensis Ducke (Fabaceae) em um fragmento de Floresta Estacional, no Semiárido do Nordeste, Brasil. Rev Árvore. 37(4): 657667.

Oliveira ECS, Costa Junior EO, Fernandes PD, Quirino ZGM (2019) Phenological study of populations of Cnidoscolus quercifolius in the Western Seridó, Paraíba state, Brazil. Rodriguésia. 70: 1-9.
Parente HN, Andrade AP, Silva DS, Santos EM, Araújo KD, Parente MOM (2012) Influência do pastejo e da precipitação sobre a fenologia de quatro espécies em área de Caatinga. Rev Árvore. 36(3): 411-421.

Paz WS, Souza JT (2018) Fenologia de espécies vegetais arbóreas em um fragmento de Caatinga em Santana do Ipanema, AL, Brasil. Diversitas J. 3(1): 39-44.

Ribeiro SM, Bonilla OH, Lucena EMP (2018) Influência da sazonalidade e do ciclo circadiano no rendimento e composição química dos óleos essenciais de Croton spp. da Caatinga. Iheringia, Série Botânica. 73(1): 31-38.

Rocha TGF, Silva RAR, Dantas EX, Vieira FA (2015) Fenologia da Copernicia prunifera (Asteraceae) em uma área de Caatinga do Rio Grande do Norte. Cerne. 21(4): 673-682.

SAS Institute Inc. (2008) SAS/STAT 9.2 User's Guide. Cary, NC, SAS Institute Inc.

Silva JMC, Leal IR, Tabarelli M (2017) Caatinga: The larguest Tropical Dry Florest Region in South America. Springer International Publishing, Cahm. $506 \mathrm{p}$.

Souza DNN, Camacho RGV, Melo JIM, Rocha LNG, Silva NFS (2014) Estudo fenológico de espécies arbóreas nativas em uma unidade de conservação de Caatinga no Estado do Rio Grande do Norte, Brasil. Biotemas. 27(2): 31-42.

Zar JH (1996) Biostatistical analysis. Prentice-Hall, New Jersey. $662 \mathrm{p}$. 